\title{
Should we teach first language grammar in compulsory schooling at all? Some reflections from the Spanish perspective
}

\begin{abstract}
This text explores the controversial issue of grammar teaching in Language Arts. It considers the importance of grammar in schooling based on the learners' reflection on language (i.e., their "metalinguistic activity"), and some of the features of such a reflection. A model of intervention is presented as well as its particularities, especially the goal of establishing new dimensions with regard the methodology of teaching, the conception of grammar, and the final objectives of grammar instruction. The text ends by referring to some of the challenges for the future.
\end{abstract}

Keywords: school, language use, grammar, reflection, metalinguistic activity, instructional sequence.

\section{Teaching language is teaching how to use language}

For some years, the role of grammar teaching has been the subject of intense debate in the international context. While on occasions it has triggered enraged controversies that go beyond the academy (e.g., the case of England, see Cameron 1995), such teaching is considered necessary by studies conducted in a number of countries in which the debate ranges from a general consensus to an increasing need to re-think its role and recover its value in Language Arts (Myhill 2009; Locke 2010; Hudson 2016; Giovanelli \& Clayton 2016; Pieniążek \& Štěpáník 2016; Boivin, Fontich, Funke, García-Folgado \& Myhill 2018; Rattyä, Awramiuk \& Fontich 2019). While such studies have been conducted in accordance to country-specific idiosyncrasies, three general ideas are shared: grammar knowledge plays an important role in improving language use (especially in writing), such a role is still underexplored, and there is a need to further unpack the "grammar knowledge / language use" connection. Grammar knowledge is seen as a tool that might help students move

1 Address for correspondence: Universitat Autònoma de Barcelona, Departament de Didàctica de la Llengua i la Literatura, i de les Ciències Socials, Facultat de Ciències de l'Educació, Edifici G5, Campus UAB, 08193 - Bellaterra (Cerdanyola del Vallès, Barcelona, Spain). E-mail: xavier.fontich@uab.cat 
beyond reproducing their own colloquial oral registers in the written or formal oral forms. The assumption is that grammar knowledge allows us to become aware of the distance between written and oral modes, the rhetorical possibilities language affords, and the ways of writing texts that respond to diverse demands, such as the degree of lexical repertoire or the cohesive syntactic style. Such command is of utmost importance in some compulsory school assignments and in academic writing in general, as well as in several jobs and professions that involve the capacity to handle dictionaries, translators, or style books. Also, some grammar knowledge should be considered part of citizens' general culture at the same level as history, and the sciences. ${ }^{2}$ Yet, while grammar knowledge is considered paramount, researchers wonder whether it should be approached incidentally within language use or temporarily detached from communication. This materializes in two conflicting questions. First: Should we zoom in on grammar contents (either implicitly or explicitly) always within the context of language use and do so only whenever grammar problems arise? Or (second question) should we explicitly address the teaching of the grammar system assuming that this allows students to become more competent in using language?

With regards to the first question, some suggest that to broaden the repertoire of students' linguistic resources, direct instruction of grammar concepts might not be completely desirable, as it is decontextualized and therefore very removed from language use (and generally very tedious, too, some maintain; see Locke 2010; Camps \& Fontich 2019). This perspective suggests that to explicitly explore how the texts work might be possible by only promoting reflection on specific aspects (e.g., adjectives), with no need for metalanguage some consider (see Gil \& Bigas 2014), or by engaging students in activities of manipulation of linguistic data (e.g., sentence combining), which would raise language awareness and trigger implicit grammar learning. Thus, the students would assimilate implicitly the resources that should be put into play when writing (see Graham \& Perin 2008; Andrews 2010). This reflects a pragmatic attitude pointing to a fact recognized by reliable studies: the difficulty students have in retrieving their grammar knowledge in situations of language use, namely a gap between declarative and procedural knowledge (Camps et al. forthcoming). For some (such as those responsible for the official curriculum in the region of Barcelona), we should optimize time, resources, and efforts and teach them only that which is useful to write well, "shunning a grammaticalist approach to language teaching" (Departament d'Ensenyament, p. 39).

Contrariwise, the second question suggests that grammar knowledge located within a well-articulated grammar system is essential, assuming Vygotsky's (1987) claim that a concept becomes recoverable for conscious and deliberate control only when it is part of a system. This resonates with a basic question such as "What does 'knowing a language' mean?" (Milian 2014): Does it mean knowing how to use it? Or does it entail being able to set up an articulated and explicit reflection upon it as well, which would only be possible with adequate tools within a conceptual system (in order to be able to see the window and not just the landscape, in the well-known metaphor

2 Regarding second language acquisition and the importance of grammar knowledge, see convincing arguments in Larsen-Freeman (2003), van Lier (2004) or Ellis (2010). 
by Garton \& Pratt 1989)? A number of authors consider the latter a much more fine-tuned position, which maintains that knowledge about the system that emerges from knowledge of language in use is not articulated and does not allow the apprentice to retrieve it in a variety of situations (Camps 2014; Hudson 2016). And yet, as pointed out, research also shows that grammar knowledge might rapidly become no more than a reified and inoperative set of concepts detached from language use by an unbridgeable gap (Fisher 2004). To deal with this, Camps (2014) and Milian (2014) maintain that it is crucial to raise learners' awareness on a twofold basis: we can study the grammar of a language as a system that can be approached on its own (temporarily detached from communication); and we can study language as communicative activity. While advocates of the "grammar-in-use-only" warn against the risk of a "decontextualized" (and therefore meaningless) grammar instruction, a number of authors (e.g., Zayas, forthcoming), drawing on functionalist perspectives, conceive grammar as an organic interplay between meaning, intentions, and form, and therefore wonder whether such an expression as "decontextualized grammar" is in fact an oxymoron, since any single linguistic instance (even if detached from actual communicative contexts) would be loaded with potential meanings in connection with potential intentions.

The idea of decontextualized grammar has its roots in formal linguistic models that draw on the autonomy of syntax as a formal system detached from meaning, culture, and speakers' intentions. Yet, according to Halliday and Mathiessen (2004: 31), "Language is as it is because of the functions in which it has evolved in the human species". In this same vein, Coseriu (1991) sees language as a human-specific activity, recognizable in the form of an always addressee-oriented discourse, which makes dialogue the essence of language. As a meaning-making device, language would have epistemic potential underpinning any process not only of thought but also of knowledge. This suggests that linguistic activity shapes the very mediational process of learning language itself, which resonates with Taylor's (1997) position regarding reflexive discourse and its dialogic-interactional nature. This author maintains that we manage our experience of language by referring to it in specific, culturally-enforced, and interactionally-mediated ways: "Metadiscourse-mediated analyses are as much a part of the thing (language) itself as they are about the thing itself" (Taylor 1997: 16, italics in the original).

Also, Martin \& Rose (2007) suggest that to construe a text, when writing or speaking, both the language system and culture of composition of a text based on genre knowledge (i.e., genres acquired from former practice) are activated. This resonates with Voloshinov's (1977) methodological programme of language study that entails a top-down process of analysis: analysis of social interaction and the conditions that make it possible (i.e., human activities in which language production is enacted); analysis of global structure and properties of language products (or genres); and analysis of internal structure of genres (i.e., parts of the texts, semantic-syntactic structures, and words). This seems to align with Lantolf \& Thorne's (2006) "Linguistics of Communicative Activity" (LCA), Agar's (1994) "Languaculture", and van Lier's (2004) understanding of language as a social semiosis. 
Marta Milian expresses the grammar/use relationship with a metaphor (personal communication, 1 June 2016): a chair is for sitting (i.e., using it), but if we sell chairs we will have to pay attention to aspects such as the materials of which they can be composed according to different uses, the tools we will need to manufacture them, the design and the ergonomics or fashionable colours of the moment, etc. (i.e., what we could call "its system"). Likewise, knowledge on the grammar system would be essential in highly formal situations (e.g., a scientist who must submit an academic paper, a radio journalist on air), which require conscious attention to several issues (e.g., lexical repertoire, prosody, etc.) and a high command on grammar conceptual tools. This will coexist with informal situations in which the conscious focus on the system will not be necessary (e.g., the scientist and the journalist meet for a casual chat). ${ }^{3}$ In Spain, Gil \& Bigas (2014) and Gil \& Bigas (forthcoming) have explored the role of grammar in Language Arts in primary education (ages 6 to 12). They show the surprising capacity of some early primary graders (aged 7-8 years of age) in generating rich, original and interesting reflections. One of the tasks analysed is "peer-dictation" with "scripta continua" style, i.e. with no spaces or other marks between the words or sentences in the text. The students must discuss where the words end. When comparing the reflection triggered by late graders' (students aged 11 and 12 years old) in a similar activity, the researchers conclude that the latter develop poorer and less exploratory dialogues.

The authors wonder about the causes of this phenomenon, which has also been observed at secondary (ages 12 to 16) and Baccalaureate (ages 16 to 18) levels by Rodríguez-Gonzalo (2015) and Zayas (forthcoming). Why does it happen? A first answer might be in the correlation between children's interest in grammar and their interest in the world in general. This world becomes progressively more complex and requires concepts and procedures that guide our gaze and facilitate the transition to a gradually more sophisticated and structured observation. The increased complexity may serve to integrate new knowledge, which in turn may increase our capacities for analytical observation.

School does not seem to find ways to articulate students' curiosity about such an incredible phenomenon as language and to provide adequate scaffolding that stimulates such reflection. Several authors point to the need to review two basic issues: grammar content (what we teach), and the processes of teaching and learning (how we teach and how we learn) (see Hudson 2016; van Rijt, de Swart \& Coppen 2018).

\section{The grammar content: Linguistics and the teaching of grammar}

Some highlight the need to unravel the conception we have of grammar, emphasizing that addressing grammar as a formal rule system detached from speakers and culture can be an obstacle when it comes to interrelating grammar and school use. They consider that grammar should be conceived as a set of resources inherent to communication and meaning, a structured linguistic

3 In the field of L2, Bialystok's notions of "analysis" and "control" have served for an in-depth exploration of this double approach; see Matley (2012) for a revision. 
repertoire of concepts (e.g., sentences) and procedural possibilities (e.g., combination of sentences) that would respond to the speakers' communicative needs and intentions (e.g., adapt our text to the addressee). Some also consider that this perspective can help to make systematized grammar knowledge more recoverable in use (Myhill, Jones, Lines \& Watson 2012; Fontich 2014, 2016; Myhill, Jones \& Wilson 2016).

In Spain, although the communicative discourse took over since mid-1990s, grammar teaching remained underpinned by a sentence-level approach, inspired by formal models and apart from language in use. Nonetheless, over the last years usage-based approaches complementary to sentence-based approaches have been developed, both in the field of linguistics as well as in education. These approaches are underpinned by the idea that metalinguistic activity plays an important role both in using the language and in learning grammar (Camps \& Fontich, forthcoming).

What is the role of linguistic models in building a school grammar based on such a perspective? One of the questions raised is whether school must take linguistic models as a reference or develop its own school model. In Spain (see Fontich \& García-Folgado 2018), while some maintain that the most reliable linguistic postulates (namely, perceived as hegemonic) should be adapted to the school context, some others take the school challenges as a starting point to suggest ways that help to respond to learning needs. In both cases the work on basic sentence notions is considered, but it is the former perspective that has remained fully installed in textbooks, syllabuses, and teachers' imaginary, although the latter has been widely developed by research conducted in close collaboration with teachers proving to be more beneficial for grammar learning.

In this sense, therefore, we must continue pointing out that school and linguistics have different goals (see Chomsky's response in "Discussion", Chomsky 1988: 179-82). The goals of a pedagogic grammar and those of linguistic theories are not and cannot be coincidental. A linguistic theory is the result of a set of principles aimed at conforming a model of how reality is and meant to be put under constant scrutiny. The school will have to resort to the theory (in fact, to the plethora of theories available) not as a whole but choosing the most widely accepted ideas (Hudson 2010) and above all the most profitable and adequate ones regarding the school challenges (Camps 2014). In this respect, all teaching and learning objectives can be subsumed within a single and broad goal: the development of students' explicit communicative repertoire.

This position suggests that linguistic models should stop being regarded as the solution to how to act in the classroom, and that a comprehensive school grammar should help to re-think a number of aspects, such as clearly identify the objectives of studying grammar and the partial aspects that the students have to know (e.g., correlation among past tense forms, the relationship between verb and argument, etc.); involve students in the collection of data that will be subsequently observed (to contrast, for example, the oral and written modes); and adopt a conception of grammar as an organic interplay between morphosyntax, semantics, and pragmatics (see above).

Let us look at the latter, exploring the following sentence in Spanish: Al final del partido, llueven toda clase de objetos sobre el árbitro ('At the end of the game, all sorts of objects rain down on the referee'). This is a plausible sentence (also in Catalan), with a peculiar use of the verb. In its pro- 
totypical meteorological use, this verb does not admit arguments (semantics), and it is a defective verb with no plural (and no $1^{\text {st }}$ and $2^{\text {nd }}$ grammatical persons) (morphosyntax); however, the sentence is completely acceptable and adequate, a deviant use that responds to the utterer's intentions (pragmatics). These intentions might not be satisfied with two close verbs such as fall and throw. Indeed, fall (in Spanish caer) can connote a high number of elements involved but also a small number, unlike rain (in Spanish llover): we say Caer cuatro gotas (literally 'Fall down four drops', referring to a very light rain) and not Llover cuatro gotas ('Rain four drops'). On the other hand, throw inherently implies the presence of an agent, whether we mention it explicitly or not (Spanish is a pro-drop language), while rain allows us to hide it as a zero-argument verb.

Who could resort to such use? Without a doubt, a very partial observer who wants to minimize the uncivil behaviour of the spectators in football stands. Manuel Vázquez-Montalbán (19392003), the acclaimed Spanish writer and journalist and unconditional supporter of Barcelona football team, does so in the memorable chronicle of a paramount final between this team and Real Madrid back in the early 1970s, when football and politics were intertwined more than ever. The referee E. C. Guruceta (involved in illegal gambling) awarded a non-existent penalty to Real Madrid just three minutes before the final whistle blows, causing trouble in the stands and pitch invasion. In his chronicle, Vázquez-Montalbán maintains that "The cushion rain is impressive [...] Today is a celebration, everyone can breathe freedom and the night has the most propitious colors". ${ }^{4}$ In our former sentence, the use of the verb llover (in the form llueven, 'rain') has morphosyntactic consequences: agreement with a plural and postponed subject ("toda clase de objetos", 'all sorts of objects'); mandatory presence of preposition such as sobre (on) (bajo 'under' would sound strange) that serves to reflect on the Prepositional Complement (of great tradition in Spanish linguistics and largely explored in our schools); and the possibility of replacing in Catalan the core of the Noun Phrase with the partitive pronoun (namely, the non-finite accusative pronoun en: En plovien de tot tipus, d'objectes) as happens with unaccusative verbs (such as caure 'fall', as in: En queien de tot tipus, d'objectes, something like 'All kinds of objects kept falling').

As already suggested, some highlight the need to overcome the strictly formal approach to grammar description, inherited from the largely assumed autonomy of syntax of some theoretical persuasions. Rather, they suggest the benefits in school of approaching grammar as the organic union of morphosyntax, semantics and pragmatics. Connection between the three domains may vary and concepts of a diverse order (lexicon, sentence, text, discourse) coming from different models can be useful if they serve to articulate students' reflection. To solve agreement errors, concepts from sentence-level models (e.g., morphemes, complementary distribution, dislocation) will be relevant. To solve questions of lexical choice, there may be more pertinent notions coming from discourse-level contributions (e.g., adequacy, addressee, lexical repertoire, etc.) (Fontich 2014, 2016 and 2018). This may help when addressing the phenomena through observation and discussion

\footnotetext{
4 The reference to the "cushion rain" might sound odd; at the time, some of the seats on the expensive stands in Spain used to have cushions on them.
} 
(through a collective process of "grammaring", see Larsen-Freeman 2003). We thus enter the issue of methodology.

\section{An intervention model: When teaching-learning processes and classroom research meet}

Albeit still in minority, several contributions in Spain have underlined the need to propose new ways of teaching grammar as a hypothesis for meaningfully learning it (e.g., Fontich \& Camps 2014; Camps \& Fontich, forthcoming). These studies question whether a more constructivist way that contemplates a methodological change would help to improve the learning of grammar: i.e., methodology as content also of teaching and learning and not as a simple cosmetic option (Camps, forthcoming). ${ }^{5} \mathrm{~A}$ proposal of classroom intervention to teach grammar based on sociocultural tenets should promote interaction as a means for learning. Since, according to a sociocultural point of view, the learner does not learn from the knowledge of the expert but from the (intentionally designed) activities in which the expert involves the learner (Miller 2011), metalinguistic interaction could be considered a source of grammar learning (Camps 2014). Interaction may as well constitute an instrument of formative assessment and reflection for the teacher. To respond to this need, the so-called model of Grammar Instructional Sequences (GIS) has been developed (see Milian 2014).

This model overcomes a purely transmissive vision of language teaching and assumes the active and constructive role of the learner. It highlights the need for global approaches to the teaching of grammar beyond isolated tasks and suggests the enormous possibilities of the project work in designing teaching settings based on classroom interaction. It integrates oral and written speech as well as language use and reflection on this use and seeks to create a diversity of learning opportunities and therefore the possibility of participation of learners with diverse skills. It articulates a set of activities always oriented towards an explicitly stated objective, organizing the sequence of activities into three phases (preparation, execution, and closure), always comprising the writing of a final report.

This model is governed by what is known as the criterion of "elementality" (Coronas 2014), according to which an initial nucleus of prototypical and operative notions will give way to a subsequent set of notions, progressively more complex and articulated via cognitive conflict. And finally, it foresees three sub-models of intervention according to whether the focus is on use, on the system or on the contrast between languages or between dialects of a language. The three sub-models are based on the idea that different approaches to grammar may contribute differently and in equally important ways to the articulation of grammar knowledge (Camps, forthcoming; Milian 2014). They have been widely contrasted in the classroom by teachers of different levels (see Fontich \& García-Folgado 2018; Camps \& Fontich forthcoming).

A. Focus on language use. Examples: contrast a piece of news and a short tale exploring sentenceand text-level properties; explore headlines observing sentence semantic patterns in connection to

5 This is clearly in line with the position that researchers in other educational jurisdictions maintain, see Fontich 2018 for a summary. 
verbal arguments; combine activities of transformation, textualization, integration, contrast, etc. to explore strategies of cohesion within a text.

B. Focus on the language system. Examples: adopt a lexical perspective to contrast sentences and semantic patterns; classify the verbs from the variable number of verb-complements in real uses to explore the notion of transitivity; set up discussions on what students understand by specific grammar concepts (e.g., past tense, sentence, pronoun, verb, etc.).

C. Focus on inter- and intra- linguistic contrast. Examples: approach the notion of dialectal variation by exploring some uses of recessive pronouns in urban areas; reason about the lack of isomorphism among languages regarding certain pronominal or verbal uses; contrast the results of automatic translators.

The idea that triggers such an approach is that the code can be an interesting object of exploration if students are actively involved in the construction of their own knowledge, for which collaborative work and interaction are paramount. It has been carried out in diverse classrooms and has also constituted in some cases the focus for research. Next (Table 1), we detail three studies based on such premises.

Table 1. Features of the three studies

\begin{tabular}{|l|l|l|l|l|l|l|l|}
\hline Study & $\begin{array}{l}\text { Kind of } \\
\text { intervention }\end{array}$ & $\begin{array}{l}\text { Case study } \\
\text { methodology }\end{array}$ & Focus & Concept & School level & Dynamics & Data \\
\hline $\begin{array}{l}\text { I. Casas-Deseures } \\
(2012)\end{array}$ & $\begin{array}{l}\text { Seminatural } \\
\text { Intervention }\end{array}$ & Interview & $\begin{array}{l}\text { Grammar } \\
\text { system }\end{array}$ & Present tense & $\begin{array}{l}\text { Primary } \\
11-12 \text { years }\end{array}$ & In pairs & Oral \\
\hline $\begin{array}{l}\text { II. Fontich (2010) } \\
\text { Natural } \\
\text { intervention }\end{array}$ & $\begin{array}{l}\text { Action } \\
\text { research }\end{array}$ & $\begin{array}{l}\text { Grammar } \\
\text { system }\end{array}$ & Verb compl. & $\begin{array}{l}\text { Secondary } \\
13-16 \text { years }\end{array}$ & $\begin{array}{l}\text { In small } \\
\text { group }\end{array}$ & Oral \\
\hline $\begin{array}{l}\text { III. Rodríguez- } \\
\text {-Gonzalo (2015) }\end{array}$ & $\begin{array}{l}\text { Classroom } \\
\text { intervention }\end{array}$ & Observation & Writing & Past tenses & $\begin{array}{l}\text { Secondary } \\
15-16 \text { years }\end{array}$ & $\begin{array}{l}\text { In small } \\
\text { group }\end{array}$ & $\begin{array}{l}\text { Written } \\
\text { \& Oral }\end{array}$ \\
\hline
\end{tabular}

Study I is dubbed "seminatural intervention" as it is conducted by a researcher within the school context outside the class. Study II is a "natural intervention" as it is designed, implemented, and analysed by the regular teacher. Last, Study III is considered a "classroom intervention" as it is implemented by the regular teacher but designed and analysed by the researcher. While the three of them share the same principles, studies II and III are organized as a grammar instructional sequence. The transcription of the oral data is based on spelling transliteration (reflecting only basic features of the interaction, such as pause-length), ${ }^{6}$ the focus is in the content, and analysis and categorization of data are inspired by the so-called grounded theory (Corbin \& Strauss 2008),

6 The transcription criteria used are: number of the Dialogue, number of the turn, given name (for student anonymity), "Researcher” (for researcher's turns), “...” (Segment object of reflection), XXX (Segment not understandable), :: (extension), | (pause less than 3 seconds), <... (pause of 3 seconds or more). 
which systematizes the answers according to the task and interprets them in light of the theoretical framework that guide each research.

Hereafter are briefly presented the three studies (see Casas-Deseures, Durán \& Fontich, forthcoming; Rodríguez-Gonzalo 2015) that respectively explore students' reflection on the present tense with retrospective value, variations in verbal transitivity, and the complex subsystem of past tenses. They assume that observing certain non-prototypical behaviours (i.e., deviating from what is habitual; Ungerer \& Schmid 2006) and doing so in peer or small group interaction can generate cognitive conflict and trigger questions and discussion and, therefore, metalinguistic activity. School practices tend to address sentence phenomena twofold (see Brucart 2000; Coronas 2014): prioritizing descriptive and formal aspects before pragmatic and semantic aspects; and exploring prototype uses, assuming implicitly that non-prototype constructions should be left to more advanced levels (as the most regular aspects would provide security to the apprentice). Yet, some studies show that focusing on prototypical behaviours only can generate a reified grammar knowledge, which would be inoperative in the context of grammar reflection, as well as difficult to transfer to situations of real use (see above).

\section{Study 1: "When does it happen?"}

This study (Casas-Deseures 2012) explores how 86 late primary graders (11-12 years old, Catalan as L1 or L2) from 3 schools near Barcelona build knowledge about the values of the present. The task presents a set of sentences, such as "In 1969 man reaches the moon", in which the present tense has a retrospective value, showing non-coincidence between the time of the statement (expressed with a temporary modifier "in 1969") and time enunciation (expressed with the present tense "reaches"), in a retrospective non-prototypical use. The distinction between prototype and peripheral values of verb tense has been widely explored by grammars. Pérez-Saldanya (2002) points out that the present has a basic layout indicating "simultaneity with respect to the moment of the speech act" (p. 2.618), while it can express less marked values, such as retrospective, prospective, habitual or timeless. One of the questions asked is "What kinds of strategies do pupils use to uncover the tense of a sentence?" Following Klein's (2009) and Tartas' (2009) studies on how pupils express tense and on their evolutionary construction of tense notions, the analysis reveals three strategies the pupils follow: morphological (the tense is indicated by the morphemes, see Dialogue 1), semantic (the tense is indicated by the temporary modifier "in 1969", see Dialogue 2) and experiential or world-knowledge based (see Dialogue 3).

\section{Dialogue 1. Morphologic strategy (couple 1)}

1. Researcher: when does it happen? | when does what the sentence talks about happen?

2. Maria: now | present tense | otherwise it would say "reached" $<3>$ or "will reach" 


\section{Dialogue 2. Semantic strategy (couple 2)}

1. Montse and Pere: in 1969

2. Researcher: when is that?

3. Montse: $\mathrm{mm}::$ before $<3>$ well ::

4. Pere: in the past

5. Montse: yes :: past

6. Researcher: ok $\mid$ is there a verb in this sentence?

7. Montse: "reaches"

8. Researcher: ok / and what is that?

9. Pere: a verb

10. Researcher: ok it is a verb / but when does this verb happen?

11. Montse: $<4>$ before

12. Pere: $<3>$ in 1969

Dialogue 3. Experiential or world-knowledge strategy (couple 3)

1. Anna: $\mathrm{y}:::$ years ago :: because ::

2. R.: when does it happen?

3. Josep: when my mum had not yet been born: and my grandma had already been born.

4. R.: ah | gosh | great | but how do you know it | that this happened then?

5. Josep: because it is explained in magazines

The interaction and cognitive conflict are revealed as a productive strategy to promote metalinguistic reflection, and in one of the final dialogues, albeit in a poorly articulated way, a pupil verbalizes the possibility of several values associated to the same form ("if you use a verb in present tense $\mid$ it could also express through other words in the sentence | it could express | past | present and also future").

\section{Study 2: Classify verbs}

The second study (Fontich 2010) explores the reasoning of 75 students from $2^{\text {nd }}$ to $4^{\text {th }}$ levels of secondary school (13-16 years old, Catalan as L1 or L2, in Subject Catalan) from a school near Barcelona. These students solve the activities in small groups on the notion of verbal complementation. To observe that the appearance of complements depends on lexicosemantic and pragmatic factors (Combettes 2007), the teacher-researcher provides the students with a list of sentences and texts (see a selection in (1) - (6)) with the prototype and non-prototype uses of two complements: direct (DC) and indirect (IC). IC subsumes several values: possessive dative in (1), benefactor in (2), and experimenter in (3); and while (4) is a prototypical transitive use, (5) shows a transitive use of an intransitive verb and (6) the other way around. The objective is to classify the verbs in a graph (see 
Table 2), on the basis that this task will make students draw on their linguistic intuition as well as on comparing verbs of similar behaviour.

\section{(1) Robar steal}

[Li] ichan robat un quadre

$\mathrm{He} / \mathrm{she}$ has had a picture stolen

Literally: [To him/her] (they) have stolen his/her picture

(2) Enviar send

$\left[\mathrm{M}^{\prime}\right]$ ic han enviat aquelles fotos

They have sent those pictures to me

Literally: [To me] (they) have sent those pictures

(3) Agradar like

[Li] Ic agraden les novel · les de por

$\mathrm{He}$ / she likes thrillers / Thrillers please him/her

Literally: [To him/her] please thrillers

(4) Llegir read

Està llegint [una novel · la de por] $\mathrm{DC}$

$\mathrm{He} / \mathrm{She}$ is reading [a thriller]

(5) Viure live/enjoy

Viu [la vida] $\mathrm{DC}$ !

Enjoy life!

Literally: Live [(your)_life]!

(6) Beure drink

En Pere ja no beu $[\varnothing]_{\mathrm{DC}}$

Peter does no longer drink [Ø]

Meaning: Peter is no longer an alcoholic

Table 2. Classification of verbs in (1) to (6)

\begin{tabular}{|l|l|l|}
\hline & $\pm \mathrm{IC}$ & $-\mathrm{IC}$ \\
\hline$\underline{+\mathrm{DC}}$ & $\begin{array}{l}{[1] \text { robar steal }} \\
{[2] \text { enviar send }}\end{array}$ & {$\left[\frac{4] \text { llegir read }}{[5] \text { viu live/ enjoy }}\right.$} \\
\hline$\underline{-\mathrm{DC}}$ & {$[3]$ agradar like } & {$[6]$ beure drink } \\
\hline
\end{tabular}

Below are some brief dialogues in which students in small group try to solve the task. These dialogues show contradictory results with respect to the premise based on the benefits of non-prototype behaviours when it comes to generating cognitive conflict and triggering a reflective dialogue. 
In Dialogue 1 students must determine whether the verb robar ('steal') can be used with DC and IC. Miquel proposes a suitable example, but he himself dismisses it after a long pause:

\section{Dialogue 4 (Group I, 14-15 years of age)}

1. Miquel: and this does not fit in because | "She stole Peter a picture " $<3>$

2. Carles: no| "She stole a picture ::"

3. Miquel: | it does not sound well

4. Carles: "in Peter's house"

5. Assumpta: well | it does sound well | let's see | "She stole::"

It is a contradictory situation, since the dismissed example has just been proposed by the student and accepted by his companion. The explanation for this blockage can be found in the nonprototypical possessive dative subcategorized by the verb robar ('steal') in Catalan (also in Spanish) (while the dative explored in school has usually the prototypical value of "addressee"). Such a non-prototypical feature would be an obstacle to the correct identification of verbal behaviour, despite the context of interaction caused by the classification task. Nonetheless, we find in Dialogue 2 the opposite situation, with a cascade-like reasoning to explore to what extent an intransitive verb (viure 'live') can carry DC:

\section{Dialogue 5 (Group II, 13-14 years of age)}

1. Pere: yes | but it is a nonsense to say "what do you live? | life"

2. Jofre: so::? | but it is a sentence

3. Pere: "what do you live? life"?

4. Raquel: but you can say something other than life

5. Domènec: no:::: | "I live the world?"

6. Jofre: "I live football"

7. Domènec: |yes

8. Francesc: "I live basketball"

9. Domènec: it would fall into the direct complement slot |

In previous turns, the possibility of a transitive use for viure ('live') has been discussed, now ruled out by Pere (turn 1) and Domènec (turn 5). However, the latter (turn 9) finally accepts it presumably because of the companions' proposals (in which "live" equals "enjoy"). Interestingly, in turn (4) Raquel unblocks the reasoning opening the door to other possible complement closely linked to the verb semantics. 
Studies I and II show the pedagogic potential of relatively simple tasks to involve students in grammar reasoning, as well as to uncover some problems. These tasks allow to collect data (in both seminatural and natural contexts) to be in-depth analysed.

\section{Study 3: "My best summer"}

The third study (Rodríguez-Gonzalo 2015) explores the reasoning of a group of 21 late secondary graders (15-16 years of age, Valencian as L1 or L2, in Subject Spanish) in Valencia about the past tenses in narrative texts. Research has identified a problem in students' narrative texts: the transfer into writing of their simple oral repertoire of verb tenses in the past. Students are well able to complete a grammar task about identifying a wide range of past tenses (declarative knowledge) but they are not able to use this knowledge in the writing of a narrative text (procedural knowledge). Students are limited to use "pretérito imperfecto" (e.g., cantaba, imperfect mood, 'I sang, I used to sing') and "pretérito perfecto" (e.g., canté, perfect mood, 'I sang'), but scarcely use "pretérito pluscuamperfecto" (e.g., había cantado, perfect mood indicating past in the past, 'I had sung').

This study proposes exploring the tense values temporarily detached from their writing assignment as well as the writing of a recent experience ("My best summer") with the objective that the students expand their repertoire through an iterative process of revision. The research contrasts some dialogues collected in three moments of the writing process: the planning, a classmate's revision, and the revision of one's own text. It is observed that most students $(60 \%)$ do not incorporate into the planning of the writing any past tense other than those belonging to their oral repertoire (namely, they did not use past perfect or conditional as the future within the past), despite the initial grammar activities completed successfully. On the contrary, in the final revision of the text, carried out individually after peer review, the figures are reversed and now $61 \%$ of the students can enrich their text by incorporating other tenses. This suggests that grammar peer review provides the student with the appropriate learning context to improve their stories.

Furthermore, the investigation reveals an interesting matter. Despite the final improvement, the students show very little capacity to suggest changes to peer texts in the mid-term revision. The researcher interprets this as follows. In the first version of the story the effort and attention of the students are basically focused on the semantic-pragmatic control of the text ("What might I tell"), without being able to at the same time pay attention to the grammar aspects which are the subject of the teaching. This coincides with what has already been observed by studies on written composition processes and workload (e.g., MacArthur \& Graham 2016). Peer review has caused a change of perspective: the student who reviews abandons the position of enunciator concerned about the content and adopts the position of an external observer who focuses on the grammar learning objectives. Despite this, they are not able to suggest improvements in the revised texts because the introduction of any change entails re-arranging the text. Finally, when they re-assume the position of enunciator in their own story, they become aware of the grammar objectives and it is their control of the content that serves to incorporate more past tenses. 
This experience shows how the revision of the text has led to a rich context in which to transfer the study of grammar into the linguistic use. The results indicate the importance of dialogue and reflection in the classroom, as well as the need to see teaching and research as complementary endeavours.

\section{Teaching grammar, teaching how to reflect on language}

We cannot affirm that the association between "reflection" and "grammar learning" is a new idea (see for instance Laurinen 1955, cited in Hudson 2001). Nonetheless, reflection has been misguidingly seen as an instrument to achieve a better understanding of the linguistic concepts we want the students to learn. Indeed, beyond such a reductionist position, reflection (i.e., the use of language to explore language) could be more than a pedagogic instrument or a simple second-order linguistic activity. Some authors consider that reflection occupies a very important place in using, acquiring, and learning languages. Jakobson (1960) points out that linguistic use sometimes takes language as its reference object, adopting what the Russian linguist dubs a "metalinguistic function". And Karmiloff-Smith (1992) points out that the feature that distinguishes natural languages from the language of animals is not so much their degree of sophistication as the fact that only humans can reflectively use language, i.e., use language to refer to language itself. Some authors go further and consider that reflexivity is not only a possibility that any natural language affords, but it is a characteristic that completely pervades human communication (Taylor 2000), in the form of metadiscourse strategies that go unnoticed such as "This is what he said...", "What did she mean by that?", "Excuse me, could you repeat what you said?" (see also Taylor 2000).

The teaching of grammar could be conceived as the space within language education where we provide conceptual and procedural tools to students with the double objective of: (a) converting language into an object of conscious reflection, and (b) assimilating that this reflection is the basis for appropriate and efficient language use. Highly competent users of language (e.g., linguists, writers, teachers, etc.) are usually involved in an intense metalinguistic activity juggling diverse operations (e.g., contrast, observation, combination, subtraction, etc.), with varying degrees of consciousness. This implies both attention to the system as well as attention to use (Camps 2014; Fontich 2016). School is a scenario where a constant metalinguistic process is enacted (Gombert 1990), and our aim should be to make it explicit and conscious.

While the benefits of using language to learn across school disciplines (e.g., social sciences, art, etc.) have been widely recognized (see McLeod \& Maimon 2000), the benefit of using language to learn language (both in terms of grammar concepts and the regulation of use) has been less explored (Camps 2014). That reflective use of language or "metalinguistic activity" would constitute the "what for" or the purpose of grammar teaching, which would subsume the "what" and the "how" and which would be considered the source of grammar learning (Camps 2014). The following scheme (Figure 1) reproduces this idea: 


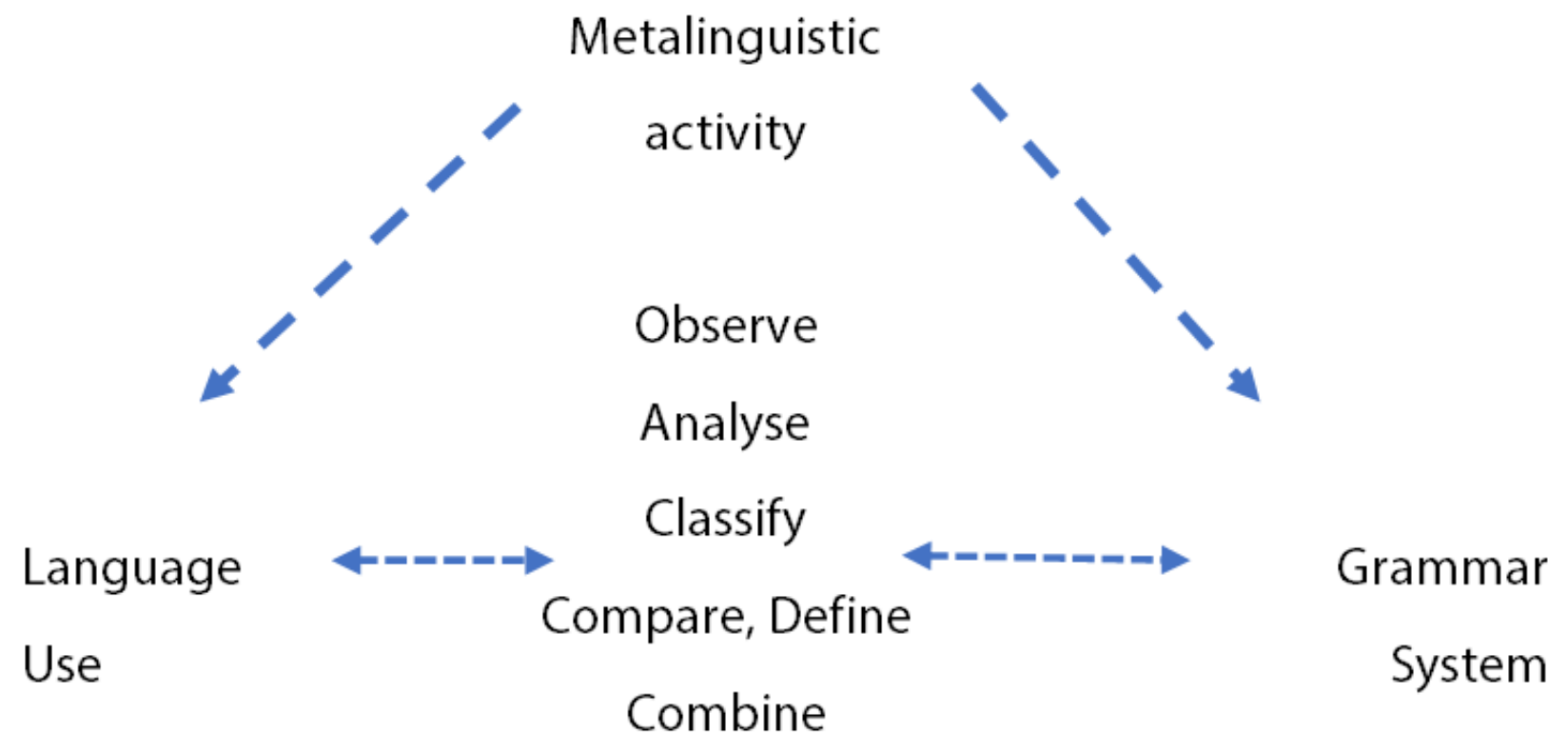

Figure 1. Metalinguistic activity (adapted from Camps 2014)

The horizon of research on the teaching of grammar is broad. A space that integrates researchers' and teachers' views and that helps to explore, develop and contrast the intervention model in the classroom needs to be created. We should be able to "translate" it into manageable consultation material aimed at both teachers and learners. It is also of utmost relevance to further develop an integrated language syllabus (i.e., spaces for reflection on the basic features shared by the different languages in the curriculum). And linking with the latter, we must find ways to articulate in a long period of time (e.g., a semester, a course, a cycle) the grammar content contemplated by the syllabus. We have stimulating work ahead. Primary and secondary teacher know that teaching language means creatively teaching how to listen, speak, read, and write. Through interaction, pupils will learn to interpret texts, develop ideas, articulate their linguistic repertoire, and put such repertoire at the service of more effective communicative skills. Teachers know that teaching language is teaching to interpret the world around us and to manage our interaction with others. In this paper grammar and metalinguistic activity have been addressed as the backbone for achieving this.

\section{References}

Agar, M. 1994. Language Shock: Understanding the Culture of Conversation. New York: William Morrow.

Andrews, R. 2010. Teaching Sentence-level Grammar for Writing: The Evidence so Far. In: T. Locke (ed.), Beyond the Grammar Wars: A Resource for Teachers and Students on Developing Language Knowledge in the English/Literacy Classroom, 91-108. London: Routledge.

Boivin, M.-C., Fontich, X., Funke, R., García-Folgado, M.-J. \& Myhill, D. 2018. Working on grammar at school in L1 education: Empirical research across linguistic regions. Introduction to the special issue. L1 - Educational Studies in Language and Literature 18: 1-6, doi: 10.17239/ L1ESLL-2018.18.04.01 
Cameron, D. 1995. Verbal Hygiene. London: Routledge.

Camps, A. 2014. Metalinguistic activity in language learning. In: T. Ribas, X. Fontich \& O. Guasch (eds.), Grammar at School: Research on Metalinguistic Activity in Language Education, 25-42. Brussels: Peter Lang.

Camps (forthcoming). Learning grammar. In: A. Camps \& X. Fontich (eds.), Metalinguistic Activity Straddling Writing and Grammar.

Camps, A. \& Fontich, X. 2019. Teachers' concepts on the teaching of grammar in relation to the teaching of writing in Spain: A case study. Contribution to a special issue What is Grammar in L1 Education Today?, edited by Kaisu Rättyä, Elżbieta Awramiuk, and Xavier Fontich. L1Educational Studies in Language and Literature 19: 1-36, doi: 10.17239/L1ESLL-2019.19.02.02

Camps, A. \& Fontich, X. (forthcoming) (eds.). Metalinguistic Activity Straddling Writing and Grammar.

Camps, A., Milian, M., Guasch, O., Pérez, F., Ribas, T. \& Castelló, M. (forthcoming). Students' grammar concepts at secondary school: The personal pronoun. In: A. Camps \& X. Fontich (eds.), Metalinguistic Activity Straddling Writing and Grammar.

Casas-Deseures, M. 2012. La construcció del coneixement sobre els valors del temps verbal del present a l'educació primària [Knowledge construction of present tense values at Primary school]. Doctoral dissertation. Bellaterra: Universitat Autònoma de Barcelona.

Chomsky, N. 1988. Language and Problems of Knowledge: The Managua Lectures. Cambridge, MA: MIT Press.

Combettes, B. 2007. Pour une sémantique grammaticale dans l'enseignement de la langue [Towards a semantic grammar in language teaching]. In É. Vargas, V. Rey and A. Giacomi (ed.), Pratiques sociales et didactique de langues [Social practice and language pedagogy] (pp.137-47). Aix-en-Provence: Presses de l'Université de Provence.

Corbin, J. \& Strauss, A. 2008. Basics of Qualitative Research: Techniques and Procedures for Developing Grounded Theory (3 ${ }^{\text {rd }}$ edition). London: SAGE, doi:10.4135/ 9781452230153.

Coronas, R. 2014. Evaluative analysis of the instructional approach to studying syntactic coordination in ten secondary school textbooks. In: T. Ribas, X. Fontich, \& O. Guasch (eds.), Grammar at School: Research on Metalinguistic Activity in Language Education, 75-110. Brussels: Peter Lang. Coseriu, E. 1991. El hombre y su lenguaje [Man and his language]. Madrid: Gredos.

Departament d'ensenyament. 2017. Currículum d'educació primària [Primary education curriculum]. Barcelona: Catalan Regional Government.

Ellis, R. 2010. Explicit form-focused instruction and second language acquisition. In: B. Spolsky \& F.M. Hult (eds.), The Handbook of Educational Linguistics, 437-55. Oxford: Wiley-Blackwell.

Fisher, C. 2004. La place des représentations des apprenants en didactique de la grammaire [The place of students' representations in grammar pedagogy]. In C. Vargas (ed.), Langue et études de la langue: Approches linguistiques et didactiques [Language and studies on language: Linguistic and pedagogic approaches] (pp.383-93). Aix-en-Provence: Publications de l'Université de Provence. 
Fontich, X. (2010). La construcció del saber metalingüístic [The construction of metalinguistic knowledge]. Doctoral dissertation. Bellaterra: Universitat Autònoma de Barcelona.

Fontich, X. 2014. Grammar and language reflection at school: Checking out the whats and the hows of grammar instruction. In: T. Ribas, X. Fontich, \& O. Guasch (eds.), Grammar at School: Research on Metalinguistic Activity in Language Education, 255-84. Brussels: Peter Lang.

Fontich, X. 2016. L1 Grammar Instruction and Writing: Metalinguistic Activity as a Teaching and Research Focus. Language and Linguistics Compass 10(5): 238-54, doi:10.1111/lnc3.12184.

Fontich X. 2018. Teaching \& Learning Guide for: "L1 Grammar Instruction and Writing: Metalinguistic Activity as a Teaching and Research Focus". Language and Linguistics Compass 12(3): 1-13, doi:10.1111/lnc3.12273

Fontich, X. \& Camps, A. 2014. Towards a rationale for research into grammar teaching in schools. Research Papers in Education 29(5): 598-625, doi:10.1080/02671522.2013.813579.

Fontich, X. \& García-Folgado, M.-J. 2018. Grammar instruction in the Hispanic area: The case of Spain with attention to empirical studies on metalinguistic activity. Contribution to a special issue Working on Grammar at School in L1 Education: Empirical Research across Linguistic Regions, edited by Marie-Claude Boivin, Xavier Fontich, Reinold Funke, María-José GarcíaFolgado, and Debra Myhill. L1-Educational Studies in Language and Literature 18: 1-39, doi: 10.17239/ L1ESLL-2018.18.04.02

Garton, A.F. \& Pratt, C. 1989. Learning to Be Literate: The Development of Spoken and Written Language. Oxford: Blackwell.

Gil, R. \& Bigas, M. 2014. The use of metalinguistic terms in writing activities in early primary school classrooms. In: T. Ribas, X. Fontich, \& O. Guasch (eds.), Grammar at School: Research on Metalinguistic Activity in Language Education, 141-72. Brussels: Peter Lang.

Gil, R. \& Bigas, M. (forthcoming). Metalinguistic activity during a task of segmentation of a text in words in early primary. In: A. Camps \& X. Fontich (comps.), Metalinguistic Activity Straddling Writing and Grammar.

Giovanelli, M. \& Clayton, D. (eds.). 2016. Knowing about Language: Linguistics and the Secondary English Classroom. Abingdon: Routledge-NATE.

Gombert, J. E. 1990. Le développement métalinguistique [Metalinguistic development]. Paris: PUF.

Graham, S. \& Perin, D. 2007. A meta-analysis of writing instruction for adolescent students. Journal of Educational Psychology 99(3): 445-476, doi:10.1037/0022-0663.99.3.445.

Halliday, M. A.K. \& Matthiessen, C. 2004. An Introduction to Functional Grammar (3 ${ }^{\text {rd }}$ edition). London: Hodder Education.

Hudson, R. 2001. Grammar Teaching and Writing Skills: The Research Evidence. Syntax in the Schools 17: 1-6. http://www.phon.ucl.ac.uk/home/dick/papers/writing.htm [1 $1^{\text {st }}$ September 2018] Hudson, R. 2010, Linguistic theory. In: B. Spolsky \& F. M. Hult (eds.), The Handbook of Educational Linguistics, 53-65. Oxford: Wiley-Blackwell.

Hudson, R. 2016. Grammar instruction. In: C. MacArthur, S. Graham \& J. Fitzgerald (eds.), Handbook of Writing Research ( $2^{\text {nd }}$ edition), 288-300. London: Guilford. 
Jakobson, R. 1960. Closing Statement: Linguistics and Poetics. In: T.A. Sebeok (ed.), Style in Language, 350-77. Cambridge, MA: MIT Press.

Karmiloff-Smith, A. 1992. The Child as Linguist. In: A. Karmiloff-Smith (ed.), Beyond Modularity: A Developmental Perspective on Cognitive Science, 31-63. Cambridge, MA: MIT Press.

Klein, W. 2009. How time is encoded. In: W. Klein \& P. Li (eds.), The Expression of Time, 39-81. Berlin, New York: Mouton de Gruyter.

Lantolf, J.P. \& Thorne, S.L. 2006. Sociocultural Theory and the Genesis of Second Language Development. Oxford: Oxford University Press.

Larsen-Freeman, D. 2003. Teaching Language: From Grammar to Grammaring. Boston: Thomson Heinle.

Laurinen, I. 1955. The development of sentence sense in the light of the results attained in the teaching of writing in Finnish primary schools. Doctoral dissertation. Helsinki: Helsinki University.

Locke, T. (ed.) 2010. Beyond the Grammar Wars: A Resource for Teachers and Students on Developing Language Knowledge in the English/Literacy Classroom. London: Routledge.

MacArthur, C.A. \& Graham, S. 2016. Writing research from a cognitive perspective. In C.A. MacArthur, S. Graham \& J. Fitzgerald (eds.), Handbook of Writing Research ( $2^{\text {nd }}$ edition), 24-40. New York: The Guilford.

Martin, J.R. \& Rose, D. 2007. Working with Discourse: Meaning Beyond the Clause (2 ${ }^{\text {nd }}$ edition). London, New York: Continuum.

Matley, D. 2012. Exploratory Grammar Learning in a Multimedia Environment. Marburg: TectumVerlag.

Pieniążek, M. \& Štěpáník, S. (eds.). 2016. Teaching of National Languages in V4 Countries. Praha: Faculty of Education of Charles University.

McLeod, S. \& Maimon, E. 2000. Clearing the air: WAC myths and realities. College English 62: 573-83.

Milian, M. 2014. Working on grammar at school. In: T. Ribas, X. Fontich \& O. Guasch (eds.), Grammar at School: Research on Metalinguistic Activity in Language Education, 43-74. Brussels: Peter Lang.

Miller, R. 2011. Vygotsky in Perspective. New York: Cambridge University Press.

Myhill, D., Jones, S. \& Wilson, A. 2016. Writing conversations: Fostering metalinguistic discussion about writing. Research Papers in Education 31(1): 23-44, doi:10.1080/02671522.2016.1106694.

Myhill, D.A. 2009. Becoming a Designer. In: R. Beard, D. Myhill, J. Riley \& M. Nystrand (eds.), The SAGE Handbook of Writing Development, 402-14. London: SAGE.

Myhill, D.A., Jones, S.M., Lines, H. \& Watson, A.M. 2012. Re-thinking grammar: The impact of embedded grammar teaching on students' writing and students' metalinguistic understanding. Research Papers in Education 27(2): 139-66, doi:10.1080/02671522. 2011.637640

Rättyä, K., Awramiuk, E., \& Fontich, X. 2019. What is grammar in L1 education today? Introduction to EduLing special issue What is Grammar in L1 Education Today, edited by 
Kaisu Rättya, Elzbieta Awramiuk, and Xavier Fontich. L1-Educational Studies in Language and Literature 19: 1-8, doi: 10.17239/L1ESLL-2019.19.02.01

Ribas, T., Fontich, X., \& Guasch, O. (eds.). 2014. Grammar at School: Research on Metalinguistic Activity in Language Education. Brussels: Peter Lang.

Rodríguez-Gonzalo, C. 2015. A classroom intervention on Spanish grammar and writing: The use of the past tense with secondary school students. Culture and Education 27(4): 879-98, doi:10.10 80/11356405.2015.1089388

Tartas, V. 2009. La construction du temps social par l'enfant [The construction of social time by the child]. Berna: Peter Lang.

Taylor, T. J. 1997. Theorizing Language: Analysis, Normativity, Rhetoric, History. Oxford: Pergamon Press.

Taylor, T. J. 2000. Language constructing language: The implications of reflexivity for linguistic theory. Language Sciences 22: 483-99.

Taylor, T. J. 2010. Where does language come from? The role of reflexive enculturation in language development. Language Sciences 32: 14-27.

Ungerer, F. \& Schmid, H.-J. 2006. An Introduction to Cognitive Linguistics (2 ${ }^{\text {nd }}$ edition). Harlow: Pearson.

van Lier, L. 2004. The Ecology and Semiotics of Language Learning. Dordrecht: Kluwer Academic. van Rijt, J., de Swart, P. \& Coppen, P.-A. 2018. Linguistic concepts in L1 grammar education: A systematic literature review. Research Papers in Education, doi:10.1080/02671522.2018.1493742.

Vygotsky, L.S. 1987. Thinking and speech. In: R.W. Rieber \& A.S. Carton (eds.), The Collected Works of L.S. Vygotsky, Vol. 1, 39-288. New York: Plenum.

Zayas, F. (forthcoming). Towards a pedagogical grammar. In A. Camps \& X. Fontich (eds.), Metalinguistic Activity Straddling Writing and Grammar.

\section{$* * *$}

Xavier Fontich is a lecturer at the Faculty of Education of the Universitat Autònoma de Barcelona (Spain). His scholarly work pertains to language education, focusing on a variety of educational issues (textbooks, using literature in the classroom, in-service teacher education, etc.) with attention to L1 grammar instruction for writing. He has authored or co-authored papers, books, chapters, and pedagogic material on this topic, arguing that social interaction has an enormous epistemic potential in learning grammar. He is co-editor of Bellaterra Journal of Teaching \& Learning Language \& Literature, a Scopus indexed online peer-reviewed, multilingual journal that publishes research by graduate or post-doctoral students, as well as invites contributions by internationally recognized scholars. In the period 2014-2016 he was a Visiting Scholar at the Graduate School of Education, University of Exeter (UK). He worked as a secondary school teacher (1995-2014). 